\title{
Whose identity politics? - Lessons for emerging critical disability geography in Hungary
}

\author{
J. Timár ${ }^{1}$ and Sz. Fabula ${ }^{2}$ \\ ${ }^{1}$ Institute for Regional Studies, Centre for Economic and Regional Studies, Hungarian Academy of Sciences, \\ Békéscsaba, Hungary \\ ${ }^{2}$ Department of Economic and Social Geography, University of Szeged, Szeged, Hungary \\ Correspondence to: J. Timár (timarj@rkk.hu)
}

Received: 31 July 2012 - Revised: 4 February 2013 - Accepted: 12 June 2013 - Published: 7 October 2013

\begin{abstract}
In response to the economic crisis in 2009, the Hungarian government reduced the level of support for the employment of impaired people. The withdrawal of this state support has not only resulted in a massive wave of dismissals, but has also transformed some peripheral settlements into spaces of resistance. The research presented in this paper was conducted to understand the nature of political actions organised in Békés County (one of Hungary's disadvantaged regions) in order to support the social employment of impaired people. By analysing these political actions we have highlighted certain contradictions of applying the concept of identity politics in a post-socialist context, and the advantages of a combined, biosocial model. On the one hand, the outline of the political and economic situation helped us understand that the analysed social protests only resembled identity politics. In reality, they may even have contributed to the reproduction of ableism. On the other hand, by integrating individual experiences into the social model of disability we could also reveal that according to our impaired interviewees, it is not only their impairments and/or disabilities that render daily life difficult. Their firm call for changes in both economic and regional policy suggests that the deliberate and combined use of identity and class politics would be particularly important. Overall, our results suggest that it is essential for scholars in Hungary to engage more strongly in critical disability geography and to thus help the approach take root and develop further.
\end{abstract}

\section{Introduction: concepts, methods}

In September 2009, the Hungarian government not only changed the regulations concerning the social employment ${ }^{1}$ of people with impairments ${ }^{2}$, but also cut back drastically on state subsidies. Implemented in reaction to the global economic crisis, these changes resulted in the lay-off of hundreds of people in Békés County, one of the country's most economically disadvantaged regions. Consequently, a wave of protests (e.g. road blockades in rural communities, demonstrations and petition campaigns) led by local politicians of the opposition as well as local employees and their support-

\footnotetext{
${ }^{1}$ In the Hungarian context, "social employment" is synonymous with "sheltered employment", i.e. its Western counterpart.

${ }^{2}$ In Hungary, the official category for people with impairment is people with reduced capacity to work.
}

ers swept the county. Although Woods' (2003) assertions regarding rural protests, according to which neoliberal policies and social and economic restructuring lead to the emergence of new groups and movements of resistance (as opposed to earlier sector-specific pressure groups), are likely to apply to this wave of demonstrations, Hungary's socialist heritage renders protests against state policies rather rare in rural areas. Nevertheless, these protests marked the first time that impaired people had actively stood by their own interests in the context of new capitalism, thus arousing substantial media interest. In spite of these efforts, however, the protesters failed to realise their goals.

In an open letter sent to the President of the Republic of Hungary on 7 December 2009, the employees affected by shortages in government support emphasised aspects related to their group-distinctiveness, the disadvantages attributable 
to their impairments as well as the social injustice suffered as a result. If we agree that identity politics is "a concept that refers to social movements organised around the politicisation of particular cultural identities" (Pratt, 2000:367), then political activities in Békés County can be interpreted as identity politics. Adopting a critical geographical approach, our broader aim is to contribute to transforming a disabling society. In order to achieve this aim, we studied political activities in Békés County so as to consider the viability of fostering the socio-spatial spread of such activities. This is particularly important in a country where both critical geography in general (Timár, 2003) and disability geography in particular (Fabula, 2011) are still in their infancy. Notwithstanding its limitations we found identity politics to be a useful concept for our study. It helped us understand that the analysed social protest organised in support of the employment of disabled people only resembled identity politics. In reality, both party political and economic stakes underlie such demonstrations, which may, however, reinforce rather than weaken the ableist nature of society.

Although we strive to elaborate on this argument by applying the concept of identity politics, this is not to say that we advocate the approach. Nevertheless, we do think that discussions on disability-related identity politics rely strongly on "Western" experience, and can thus be further elaborated on. East Central Europe, where disabled people have only become "visible" following the socialist era, may offer a context that differs from the "Western" experience. Having said this, we can from an East Central European perspective only agree with widespread criticism of identity politics, according to which drawing sharp boundaries renders the forging of effective political alliances across social movements difficult (Pratt, 2000). For the time being, however, key issues in Hungary relate to the aspects of "recognition", disabilityrelated oppression and to the identification of those suffering disadvantages as a result. Therefore, in the debate which emphasises the contradictory nature of redistributive justice and identity politics or, as Fraser (1997) argues, affirmative and transformational politics, we tend to take sides with Rose (1993). We assume that identity politics may, hic et nunc, serve or function as a necessary moment, a strategy whose aim is to create group identity, foster solidarity and gain recognition before deconstruction.

It was clear when we first raised this issue that the social rather than the medical model of disability is better suited to the study of the political movements aimed at improving labour market access. This is not only due to the fact that the social model serves as a vital catalyst for the political participation of impaired people in daily practice (Barnes, 2000), but that critical research conducted on ableism is based on this approach (Chouinard, 1997). We believe that the nature of the disability-centred political actions in Békés County can only be fully understood if analysed in the multiple context of politics, power relations and economy at both the national and regional level. At the same time, however, we share the opinion that the study of political struggles requires that sufficient attention be given to both the collective and individual dimension. In line with other scholars, Watson (2004:112) recommends that the social model be revised and a new perception be created that "incorporates the experience of disabled people but at the same time maintains a political element". For this reason, we ultimately opted to apply this model labelled by Philo (2009) as biosocial in our analysis. In doing so, we are able to retain the critical approach offered by the social model whilst at the same time also acknowledging individual experiences with disablement and impairment.

Accordingly, in the first part of our analysis based on statistics, documents, newspaper articles and 21 interviews $^{3}$ with "experts", we provide a brief outline of the politicaleconomic forces underpinning the demonstrations in Békés County. Our focus on the place and scale of power relations and vested interests as geographical categories is intended to facilitate understanding. The next section summarises the experiences of impaired individuals in Békés County in order to gain insights into their political disability identity and to obtain a better understanding of why they joined (or failed to join) the demonstrations in the county. We use the concept developed by Putnam (2005) as our analytical framework as she identifies six potential domains and subdomains which structure the parameters of political disability identity and are therefore well suited to empirical analyses. As Putnam's theoretical framework is based both on broad scientific discussion and on the results of numerous empirical studies, we were able to compare the situation in Békés County with the experiences had in other countries/regions.

In order to gain insight into individual experiences, indepth semi-structured interviews were conducted with 40 individuals in Békés County in 2010 and 2011. In order to obtain information on a diverse range of identities, interviewees were selected on the basis of the following criteria ${ }^{4}$ : firstly, interviewees should be affected by social employment in one way or another; be it by way of current or former employment, or as individuals who, though impaired, did not want

\footnotetext{
${ }^{3}$ These interviews were conducted with local politicians (5), employers (3) and representatives of civil organisations supporting impaired people (4) and social institutions (9).

${ }^{4}$ Most (12 persons) were visually impaired, 6 with locomotor diseases, 3 mentally impaired, 1 person with hearing impairment and 18 persons had other degenerative or inflammatory diseases or gastro-intestinal disorders. Of the 24 women and 16 men interviewed, 4 persons were in the age range of 18 to 29,6 in the age range of 30 to 39,7 in the age range of 40 to 49,17 in the age range of 50 to 59 and 6 persons were 60 or older. Eighteen live in the county seat with a population of 70000,9 in towns and 13 in villages. As regards their income position, most (22 persons) were below the official poverty line prevailing in 2011 (i.e. a subsistence wage of HUF 78000 per person), another 16 earned an income of around the current subsistence wage (i.e. HUF 78000 to 100000 ) and only 2 had an income of over HUF 100000.
} 


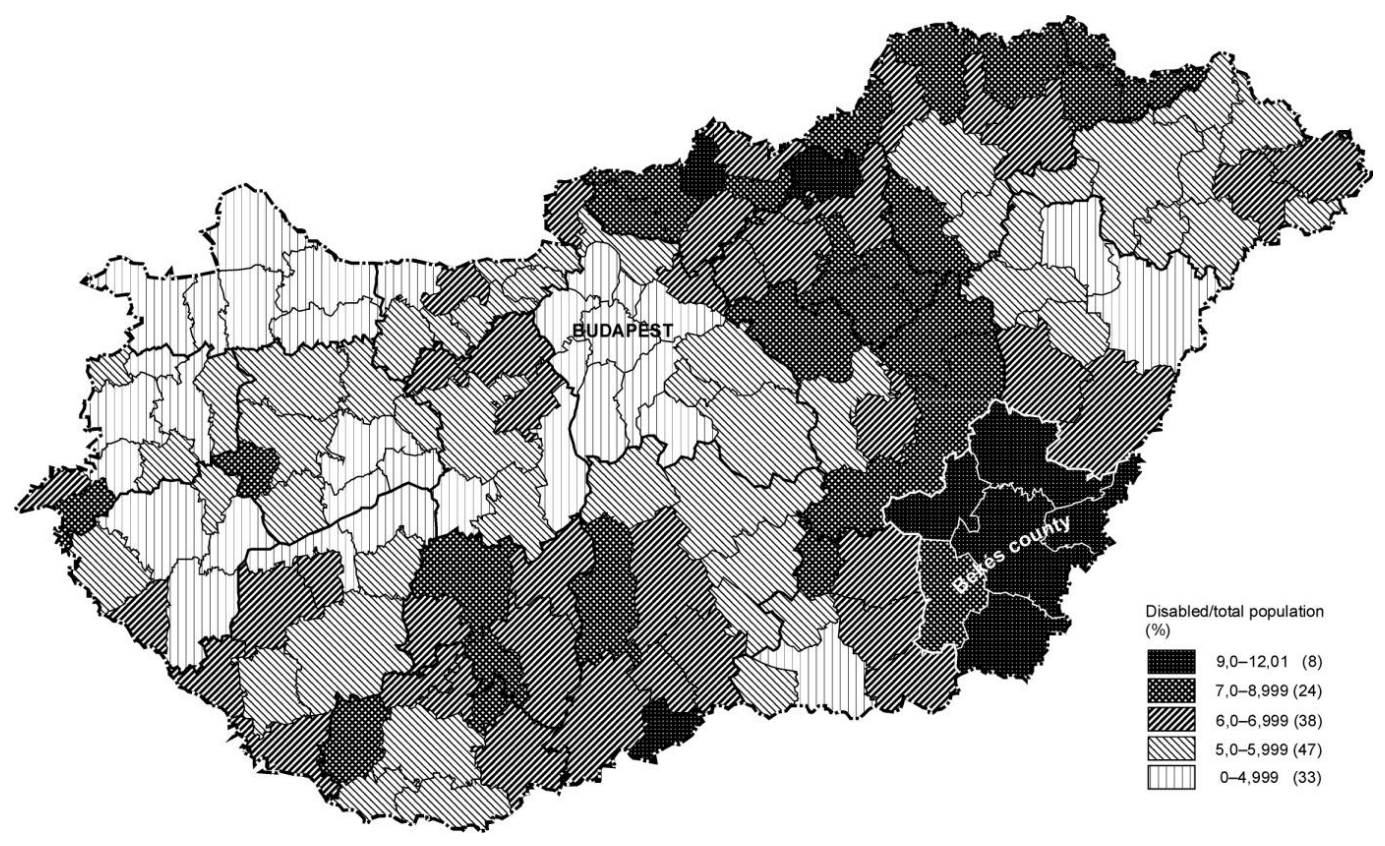

Figure 1. Rate of people with disabilities in LAU1 (NUTS4) regions of Hungary (2001). Source: Fabula by KSH (2001).

or manage to be socially employed. Secondly, opportunity should be given to both protesters and non-protesters to voice their opinions in order to assess the strength of solidarity and the existence or absence of shared political goals. Thirdly, the interview sample should cover as many types of settlement as possible, so as to reflect the situation of the county comprehensively. On the basis of these requirements two methods were used to select appropriate interviewees: (1) with the help of employers and civil organisations, (2) by means of the "snowball method". The questions asked during the interviews pertained to the following thematic issues (topics): career, state of health, education and occupation; civil participation (involvement) and networking; the home as an experienced micro-space; transport; use of space; identities (with special regard to the impact of impairments); living conditions; attitude to political actions in the county.

The summary of the study provides an outline of the most important empirical findings which underpin our major argument and includes the resulting conclusions which relate to the theoretical debates within critical disability geography on identity politics.

\section{A social and economic background to the political involvement of impaired people in Békés County}

In order to understand the nature of political actions launched in reaction to reduced levels of support for the social employment of impaired people in Hungary in 2009-2010, we first review the social, political and economic context of the demonstrations. The geographical perspective of our analy- sis is reflected in our strong focus on regional characteristics as well as in the interaction of local and national scales of power relations and interests. This geographical focus not only helps us clarify whether the political actions in Békés County can be interpreted as identity politics, but is also helpful in assessing the potential of changing the ableist nature of society that such political actions can induce.

\subsection{The political and economic situation}

Research conducted in various regions throughout the world supports the fact that impaired people as a social group are over-represented in poorer regions (Abberley, 1987; Davis, 2001). According to data collected during the census conducted prior to the 2009 political protest, the ratio of disabled $^{5}$ people to the total population was higher than the national average (5.7\%) in the economically less developed regions (thus in Békés County as well), while it was lower in the more developed ones (e.g. the Budapest agglomeration and north-west Hungary) (Fig. 1).

Following the post-socialist economic restructuring, Hungary and thus also Békés County experienced an explosion in the rate of unemployment. Under the prevailing statutory regulations, some impaired people were eligible for welfare benefits (e.g. state support, disability pension) providing that they agreed to being labelled as "disabled". Thus, this

${ }^{5}$ The interpretation of the term "disabled" in accordance with the individual/medical model is still more prevalent in public parlance and official documents in Hungary. In effect, the census used the categories of "impaired" and "disabled" interchangeably. 
procedure was often adopted as a survival strategy which was also confirmed by a number of our interviewees striving to find an explanation for the high proportion of impaired people located in Békés County.

There are no companies that would want to invest in production [in Békés County]. The people here were too old to move some place else, so what was the obvious solution? They got themselves pensioned off citing disabilities. These people had no disabilities. Approximately two-thirds would never even have thought of seeing a physician if the economy operated properly. (a senior officer of a civil organisation also specialising in the employment of the disabled, small town)

Although meagre, welfare benefits of this kind are often the only legal source of income for impaired citizens in Hungary. Due to the ableist nature of the labour market, society is strongly polarised in Hungary as a whole. Whereas $59 \%$ of able-bodied people in Hungary were employed in 2001, only $18 \%$ of impaired people were employed in the same year; a situation that is also reflected in Békés County where only $17 \%$ of impaired people as opposed to $55 \%$ of the ablebodied were employed in 2001. In contrast to "Western" societies where similar inequalities have been the subject matter of political debates for decades (Barnes, 1992; Barnes and Mercer, 2005), the topic has only recently, as of the early 2000s, entered social discourse in Hungary.

The role of the state in supporting the employment of impaired people has undergone a series of profound changes. During the state socialist era the employment of impaired people was basically the responsibility of large state-owned companies. In the final decade of this era all employers were eventually granted state subsidies when employing impaired people $^{6}$. Although this later somewhat modified practice survived even after 1989, it was not until a socialist-liberal government entered office in 2006 that major changes occurred. It was from this point on that local government-run social institutions that had previously provided means-tested day care for the elderly were also allowed to provide employment for the impaired. Owing to the new government measures, they were now allowed to create (mostly low-skilled) jobs (involving light physical work) for both the impaired and those facing discrimination in the open labour market. Whilst the volume of state subsidy depended on the number of employees each institution employed, the operators of these institutions enjoyed a large degree of freedom over selecting their employees.

\subsection{Local responses - power relations}

Jumping on the band wagon of these new socialist-liberal regulations, a growing number of local governments applied

\footnotetext{
${ }^{6}$ Joint Decree no. 8/1983 (VI.29.) of the Minister of Finance and the Minister of Healthcare.
}

for financial support to enhance job creation at their own day care providing institutions in Békés County. Consequently, both the number of institutions and those employed within them had soared beyond the national standard. Indeed, by 2009 a total of 2518 persons had found employment in 36 social care institutions in Békés County, whereas only 1432 persons were employed in similar institutions in the entire West Transdanubian Region comprising 3 counties.

The main factor underlying these figures are the vested interests of local actors. The new state regulations outlined above provided a new tool for handling poverty and unemployment at rural scale. Private companies were also eligible for state subsidy, which covered a significant portion of the wages paid to their impaired employees. As a result, local politics and economic interests seemed to have coincided favourably, with this form of employment spreading rapidly throughout Békés County. Indeed, many agreed that this form of employment had not only contributed to creating financial security for the impaired employees, but that meaningful activities in the local community had also had a favourable psychological effect on them (Fabula, 2012). By 2009, however, this model of employment had turned out to be financially unsustainable, which was also reflected in the response of various "expert" interviewees who agreed that the central government needed to take action:

... many began to see the issue of the disabled as a business opportunity. They thought they could cash in on it. I think that the emergence of such businesses, the dilution of the special purpose organisations [i.e. those that received priority government subsidy] and a large number of problems that had surfaced forced the then government to do something about it... (senior officer of a civil organisation, county seat)

After 2006, members of the opposition (Fidesz) party were elected as councillors in both the county council and the majority of local governments in Békés County. However, they also benefited from the favourable impacts of the socialistliberal government policy which regulated social employment.

Liberal statutory regulations offered flexible opportunities. Nothing had been regulated in detail. There was only a legal framework. Nearly everything fitted in with this framework. This was good business which secured a lot of money for the local government. The scheme worked without a hitch and brought a lot of money and votes. And this is a Fidesz place, isn't it? But this [social employment scheme] was not meant to be anybody's business. (head of one of the institutions offering social employment, village)

Referring to the impacts of the global economic crisis, the government reduced the budget earmarked for the 
employment of the impaired and adopted a new application scheme which restricted the range of eligible employers in 2009. As a result, numerous previously secure jobs became precarious. Although some of the jobs were also maintained, further deterioration of the employment perspectives for the impaired or chronically ill population resulted in a wave of protest. Angered by the unjust actions of the government, the impaired population, as a previously "invisible" social group, demanded stronger recognition and more consideration for their particular interests; for the time being even in the form of identity politics.

\subsection{Identity politics?}

The protest against the abolishment of institutions offering social employment was primarily organised by opposition politicians and took place with the participation of impaired/chronically ill people ${ }^{7}$. A petition signed by 57 of the county's 67 mayors was sent to the President of Hungary, requesting his help. Another was signed by over 11000 interested parties including employees, employers and various civil organisations supporting impaired people. In addition, a number of demonstrations were also part of the protest, the majority of which took place in Battonya, a small town in Békés County.

Although by no means against the employment of the impaired, the then mayor of Battonya (also an MP) was a profound critic of the post-2006 employment model and had hinted to some local abuses. He was a politician of the governing party and thus an opponent at the general elections of the opposition politicians who had organised the protest. Many organisers of the protest accused him of being behind the government authority inspections, which became rather frequent at the time. One made no secret of why Battonya had been selected as the location of the protest:

The location is no coincidence either. It is because of the running amok of the mayor of Battonya that things have come to this point. (the then opposition party mayor, a village affected, http://www.beol.hu/bekes/kozelet/, 11 December 2009)

By the spring of 2010 the protest had subsided. Despite the fact that the former opposition party had won the 2010 elections with a two-thirds majority, not even the local politicians who had organised the protest in Békés County (and were now working in legislative jobs) were so keen to force through their demands. Whilst some of the "expert" interviewees state that the demonstrations did contribute to saving jobs to some extent, others claim that they had no tangible effect at all.

Overall, the analysis of the political and economic situation suggests that both the central government's neoliberal

\footnotetext{
${ }^{7}$ Source: Expert interviews.
}

handling of the crisis as well as local party political power struggles reinforced the ableist nature of society. By thrusting party political interests to the forefront, local political elites colonised the political protest which could have otherwise potentially turned into disability identity politics. Indeed, under the prevailing post-socialist circumstances, this movement could likely have made the problems facing disabled people "visible". The key question now is whether the fact that the demonstrations in Békés County were met with mixed feelings by the population stems from the above mentioned colonisation, the fundamentally disabling nature of capitalist social space (Chouinard, 1997; Gleeson, 1999), or from the nature of identity politics which is barely able to facilitate communication with those "deemed outside the groups" (see in Pratt, 2000). The demonstrations which had aroused large-scale media attention led to the flaring up of a debate on the Internet. Of those who joined the debate, many went as far as to question the disadvantaged position of impaired people, saying that they at least had some paid work in a place that suffers so greatly from economic underdevelopment. Due, in part, to this public attitude, it is important that the experiences of disabled people during the demonstrations noted above are examined more thoroughly.

\section{The experiences of impaired people - political disability identity}

In general, the primary aim of learning about individual experiences by means of conducting interviews is to shed light on how active participation in disability-related political actions can be enhanced in Hungary. As Putnam's (2005) aim in creating her empirically orientated concept of political disability identity was similar, we chose to use it as the analytical framework for our analysis. Given its conceptual orientation, the approach may even help to assess whether, from the perspective of disabled people, identity politics is used correctly in relation to the political actions in Békés County.

Putnam (2005) claims that the parameters of political disability identity can be structured on the basis of the following six primary domains: (i) self-worth, (ii) pride, (iii) discrimination, (iv) common cause, (v) policy alternatives, (vi) engagement in political action (Fig. 2).

Our study found that attitudes to self-worth varied enormously. Both social usefulness of disabled people and the undervaluation of this usefulness by mainstream society were voiced during the interviews.

You simply lose count of the disabled who can do superhuman things, make progress in life, and lead their life much better than those without any affliction. So really, who are the disabled? (John, 58, county seat)

The interviewees challenged the views voiced in public discourse according to which disabled people cannot work 


\begin{tabular}{|c|c|c|}
\hline Self-Worth & Pride & Discrimination \\
\hline $\begin{array}{l}\text { Belief that persons experiencing disabil- } \\
\text { ity are of the same worth as persons not } \\
\text { experiencing disability. } \\
\text { - Belief that persons with disabilities can } \\
\text { be productive contributors to society. } \\
\text { - Belief that persons with disabilities are } \\
\text { undervalued in society. }\end{array}$ & $\begin{array}{l}\text { - Claiming disability by acknowledging } \\
\text { oneself as a person with a physical or } \\
\text { mental impairment who experiences } \\
\text { disability. } \\
\text { - Believing that disability is not unusual, } \\
\text { but rather is a common human charac- } \\
\text { teristic. } \\
\text { - Believing that impairment is not inher- } \\
\text { ently negative but can become so in cer- } \\
\text { tain cultural, social, and physical } \\
\text { environments. } \\
\text { - Recognizing this characteristic as en- } \\
\text { gendering membership in a cultural } \\
\text { minority group. }\end{array}$ & $\begin{array}{l}\text { - Belief that people with disabilities are } \\
\text { negatively stereotyped. } \\
\text { - Belief that persons with disabilities are } \\
\text { typically treated differently (often nega- } \\
\text { tively) in comparison to persons with- } \\
\text { out disabilities. } \\
\text { - Belief that discrimination results in in- } \\
\text { equality of opportunity and aocess to } \\
\text { social and economic resources. }\end{array}$ \\
\hline Common Cause & Policy Alternatives & Engagement in Political Action \\
\hline $\begin{array}{l}\text { - Belief that persons with disabilities } \\
\text { share similar experiences. } \\
\text { - Belief that some of these experiences } \\
\text { should be modified or changed. } \\
\text { - Belief that the contributing factors to } \\
\text { these modifiable experiences are similar. } \\
\text { - Belief that addressing them as a group } \\
\text { issue involves the development of a } \\
\text { common political agenda. }\end{array}$ & $\begin{array}{l}\text { Belief that disability is not characteristic } \\
\text { of the individual. } \\
\text { Belief that contributors to the disabil- } \\
\text { ity experience can be identified and } \\
\text { addressed. } \\
\text { - Belief that opportunities to reduce or } \\
\text { eliminate disability and to condition } \\
\text { the disability experience are influenced } \\
\text { by public policy. }\end{array}$ & $\begin{array}{l}\text { - Belief that people experiencing disabil- } \\
\text { ity are a political constituency group. } \\
\text { - Belief that disability constituency } \\
\text { groups represent political minority } \\
\text { groups. } \\
\text { - Belief that engagement in political ac- } \\
\text { tion by, for, and on behalf of that con- } \\
\text { stituency group can effect policy change. }\end{array}$ \\
\hline
\end{tabular}

Figure 2. Domains and subdomains of political disability identity. Source: Putnam (2005:195).

productively. In their opinion, unproductive work at places involved in social employment was attributable to inefficient work arrangements and a wasteful subsidy scheme that was both uneconomical and prone to abuse.

... they employed people and were now eligible for receiving an amount [in the form of state subsidy] four, five or even six times the prevailing subsistence wage. The employers that is... and then they made them do work that was practically meaningless. So this was the perfect gold mine... (Theodore, 36, member of a civil organisation, county seat)

However, if disabled persons themselves also internalise the disparaging social attitude directed towards them, the development of a positive disability group identity could likely be hampered. This widespread social attitude is reflected, for example, in the statement made by Mary (53, former social employee, impaired, lives in a village, demonstrator), in which her profound sympathy or even pity for the disabled population becomes quite clear: "Well, I feel sorry for them, for what they are like, poor devils".

The emergence of pride as a key requirement for the development of a political disability identity is primarily hindered by the way in which the label "disabled" is dismissed rather than acknowledgement in terms of physical or mental impairment. In Hungary, too, one of the underlying reasons for this dismissal resides in the dominance of the medical model (Oliver, 1990), which also prevails in public policy. Although familiarity with other models is crucial to shaping both a pos- itive identity (Galvin, 2005) and to political participation itself (Barnes, 2000), only rarely do such models enter public discourses, as even those affected are often hardly aware of their existence.

The fact that some interviewees were expressly proud of their impairment is largely attributable to the activity of civil organisations who embrace and support the cause of disabled people. Social participation in such organisations holds the potential to foster positive impairment-related identities significantly (Shakespeare, 1993). This is, for example, reflected in a statement given by Joseph, a civil organisation member (36, county seat), who strongly stresses common human characteristics: "... you may have some disability. Even if you're healthy." Furthermore, impairment may even become a basis for a positive self-image, as is also attested in a statement made by James (24, member of a civil organisation, county seat), a visually impaired person: “I'm glad things have come to this. I mean what has happened to my eyesight. Because, but for this, I wouldn't be the person I am now." However, rare realisations of this kind are not necessarily viewed as something "engendering membership in a cultural minority group" (Putnam, 2005).

Awareness of discrimination is one of the most common triggers that induce disability rights movements. According to the respondents, discrimination is primarily based on the widespread stereotype according to which - as many put it those with physical impairments (irrespective of the type of the impairment) are not only impaired, but also "half-witted". Although deeply discriminating, this stigma is, at best, only shaken off at the individual level, with some regarding only 
mental impairment (or visually detectable physical injuries) as a disability from which they were quick to distance themselves.

Mental disability, well, that's what I'd say is a real disability... True, it's no one's fault, but, you know, somehow, to me, they [the mentally ill] are the truly disabled. (Evelin, 33, county seat, visually impaired, civil organisation member)

Therefore, it is no coincidence that only few interviewees agreed to being labelled as "disabled". Instead, many resorted to the tactic of "defensive othering" (Schwalbe et al., 2000) by which they defined "disability" in a way that precluded having to label themselves as "disabled".

A disabled person is a person that cannot do the simple work that I do. If they cannot do it at all or cannot do it in the way it should be done. Something that makes me conclude that there is something wrong with their mental abilities. (Susanna, 54, social employee, small town)

This corresponds with two core components of the "internalised ableism" described by Campbell (2008) which also alludes to the obligation of impaired people to dissociate themselves from the disabled and to comply with ableist standards. Respondents not only agreed that disabled people had to face both social and material deprivation, but also that bias linked to mental and physical abilities has serious consequences in, for instance, the labour market: “... so if you go to a place [for a job interview] and they see that you walk on crutches, now, that's already a reason for exclusion" (Joseph, 36, member of a civil organisation, county seat).

According to the respondents, the common cause underlying political activity comprises several factors. The first is class situation (working class, underclass), the second are disadvantages stemming from the economic backwardness of the county and the third relates to exclusion from the world of paid work. Whilst many respondents are indeed affected by this type of exclusion, not all blame disability as an oppressive social construction for this situation. Although most agree that the conditions they have to put up with can be alleviated by changing political agendas, only the disability advocacy organisations have actually fought for a disability policy thus far. Whereas the interviewees regarded a number of existing problems as group issues, opinions diverged over whether these problems were effectively "disability group" issues.

This determines the way in which demand for policy alternatives, which represents one of the conditions of political disability identity within Putnam's (2005) concept, evolves and develops. Although not all were willing to accept the label "disabled" explicitly, they identified a number of disabling factors in society such as labour market discrimination and general prejudices. There was broad consensus that public policy solutions were necessary. The demonstrations in Békés County were organised to demand them. However, the opinions of impaired interviewees diverged when it came to evaluating the potential of disability-orientated policies to improve both their own disadvantaged position as well as the lives of other disabled people in the region. Evidence gathered during the interviews suggests that the existence of an effective economic or regional policy is a more pressing issue.

Based, then, on the protests in Békés County, the question remains what actually characterises the interviewees' engagement in political action. First and foremost their main objective was to save jobs. The importance of place is reflected in the spatial concentration of the protests in particular areas of the county. Whereas the communities in which the mayors were involved in organising the protests were characterised by high levels of activity, in other areas impaired employees had not even heard about the demonstrations. The fact that major civil organisations only helped launch petition campaigns to support the protest and otherwise made little effort to raise awareness and mobilise their members speaks volumes.

... [the demonstration] was limited to Battonya and its surrounding area. Nothing happened here [i.e. in the county seat]. At least we, as an association, refused to get involved because there were political overtones to the demonstration too. (Ivan, 48, member of a civil organisation, county seat)

In Hungarian parlance, "political" principally means "party political". Party affiliations tend to strongly divide the population in Hungary. While some interviewees criticised the mayors of the villages they were from, for their absence, others even mentioned coercion:

... those who didn't go to the demonstration were criticised very severely. ... It was very cold... So, I said, if I couldn't bear standing about any longer [she walked on crutches], then I'd get in the car, even if it was cold, because everybody's name was on a list so they knew who hadn't come or who hadn't volunteered to participate in the demonstration. In this way, you were made to feel that you disagreed with the mayor's decision. Because it was his idea, this two-week demonstration. (Catherine, 56, social employee, village)

The personal stories of the group under review do not seem to suggest a marked presence of the six primary domains (Putnam, 2005) that structure the parameters of political disability identity in Békés County. It is the nature of identity itself as a process (Crooks, 2007; Crooks and Chouinard, 2006) that we can see evolving: whilst some distance themselves from embracing disability, others view disability as a personal problem. Although another group is already aware of 
the social embeddedness of disability, it, for the time being, still remains underrepresented. Furthermore, the protest was, in effect, not a grassroots activity, as it had been organised by prominent local politicians with a keen eye to party political interests. Because impaired people were employed at institutions operated by the local government they depended on their mayors. Thus some of those who joined the demonstrations did not feel that their participation was the result of their own free choice. A fact which, in itself, calls the identity politics nature of the political demonstrations into question. More still, the strong demand for economic and regional policies on the part of interviewees' also questions whether identity politics was the right weapon in their fight for saving their jobs.

\section{Conclusions}

The research presented here was conducted to understand the nature of political action organised in a disadvantaged region of Hungary in order to support the social employment of impaired people. Our secondary goal was to identify the positive lessons which can be drawn from this political action, which, in spite of the national level's importance, remained local. We originally hoped that the knowledge gained thus far might, indirectly, contribute to changing an ableist society. Instead we found that the protests in Békés County had not only resembled disability-centred identity politics and primarily served the interests of both local politicians and local economic actors, but had in fact even become disabling. Furthermore, our analysis has highlighted the following issues that could potentially induce new conceptual debates:

1. Disability-centred identity politics bears the danger that it underestimates the complexity of the social and power relations as well as cultural practices that such politics deal with, and reproduces the non-disabled-disabled dichotomy (Meekosha, 2005). Such tendencies were also observable in Békés County, as the protest received party political rather than broad social support. ${ }^{8}$

2. If the demonstrations had been the manifestation of disability identity politics, they could have yielded a number of positive results in Hungary's geographical and historical context. The fact that not even a temporary strategy supporting "recognition" emerged can, however, by no means be attributed to the absence of a universal disability identity, as such an identity simply cannot exist (see in Chouinard, 1997). Having said this, there ideally ought to have been a group identity that

\footnotetext{
${ }^{8}$ Since the completion of our research, after the 2010 change in government, the conservative party that came to power has cut back on social support for the disabled more than its socialist-liberal predecessor. This triggered protest on a national level where solidarity from various segments of the society was identifiable.
}

could have urged discourses advocating a transformation of the medical model of disability into a social one which, in turn, would have encouraged political involvement and solidarity.

3. As the protest against neoliberal central government policies was not organised by disabled people, they did not fully embrace it as their own. Local politicians, often in cooperation with economic actors, were able to disguise their party political interests as an action "for impaired people". A number of aspects such as "mandatory" participation and problems of accessibility were key "disabling" components during the organisation of the demonstration.

4. According to the impaired individuals (mostly underclass or working class) interviewed as part of the analysis, it is not only their impairments and/or disabilities that render daily life difficult. More often than not it is also the economically disadvantaged status of their place of residence as well as their class status that make their lives considerably harder to manage. Their firm call for changes in both economic and regional policy suggests that the deliberate and combined use of identity and class politics would have been particularly important.

We hope that our research contributes to the elaboration of international debates on disability-centred identity politics because: (i) the ableist nature of new capitalism in Hungary reflects a unique path-dependency and (ii) "Western" experiences and recommendations neither necessarily apply to the disabled population who has just emerged from "invisibility", nor to their political involvement or the fledgling debates on the nature of disability. For the time being, the most important task facing scholars in Hungary is to engage more strongly in critical disability geography and to thus help the approach take root and spread further throughout the country.

Edited by: O. Söderström

Reviewed by: two anonymous referees

\section{References}

Abberley, P.: The Concept of Oppression and the Development of a Social Theory of Disability, Disability, Handicap \& Society, 2, 5-19, 1987.

Barnes, C.: Disability and Employment, Pers. Rev., 21, 55-74, 1992.

Barnes, C.: A working social model? Disability, work and disability politics in the 21st century, Crit. Soc. Policy, 20, 441-457, 2000.

Barnes, C. and Mercer, G.: Disability, work, and welfare: challenging the social exclusion of disabled people, Work Employ. Soc., 19, 527-545, 2005.

Campbell, F. A. K.: Exploring internalized ableism using critical race theory, Disabil. Soc., 23, 151-162, 2008. 
Chouinard, V.: Making space for disabling differences: challenging ableist geographies, Environ. Plann. D, 15, 379-387, 1997.

Crooks, V. A.: Exploring the altered daily geographies and lifeworlds of women living with fibromyalgia syndrome: A mixedmethod approach, Soc. Sci. Med., 64, 577-588, 2007.

Crooks, V. A. and Chouinard, V.: An embodied geography of disablement: Chronically ill women's struggles for enabling places in spaces of health care and daily life, Health Place, 12, 345-352, 2006.

Davis, L. J.: Identity Politics, Disability, and Culture, in: Handbook of Disability Studies, edited by: Albrecht, G. L., Seelman, K. D., and Bury, M., Thousand Oaks, California and London, Sage, 535-545, 2001.

Fabula, Sz.: Challenges for Hungarian Geography: Perspectives of "Disability Studies" in Hungary, Forum Geografic, 10, 235-243, 2011.

Fabula, Sz.: A szociális foglalkoztatók mint "terápiás helyek" kritikai vizsgálata, in: A társadalomföldrajz lokális és globális kérdései, edited by: Pál, V., Szeged, SZTE TTK Gazdaság- és Társadalomföldrajz Tanszék, 231-241, 2012.

Fraser, N.: Justice Interruptus: critical reflections of the "postsocialist" condition, London, Routledge, 1997.

Galvin, R. D.: Researching the disabled identity: contextualising the identity transformations which accompany the onset of impairment, Sociol. Health Ill., 27, 393-413, 2005.

Gleeson, B. J.: Geographies of Disability, London, Routledge, 1999.

KSH (Central Statistical Office): A fogyatékkal élők adatai, Budapest, 2001.

Meekosha, H.: A feminist/gendered critique of the intersection of race and disability: the Australian experience, http://www.wwda. org.au/vancouver1.pdf, 2005.
Oliver, M.: The politics of disablement, London, Macmillan, 1990.

Philo, C.: Disability, in: The Dictionary of Human Geography, 5th Edn., edited by: Gregory, D., Johnston, R., Pratt, G., Watts, M. J., and Whatmore, S., Malden, Oxford, Wiley-Blackwell, 164-165, 2009.

Pratt, G.: Identity politics, in: The Dictionary of Human Geography, 4th Edn., edited by: Johnston, R. J., Gregory, D., Pratt, G., and Watts, M., Oxford, Blackwell, 2000.

Putnam, M.: Conceptualizing Disability: Developing a Framework for Political Disability Identity, Journal of Disability Policy Studies, 16, 188-198, 2005.

Rose, G.: Feminism and Geography, The Limits of Geographical Knowledge, Oxford, Polity Press, 1993.

Schwalbe, M., Godwin, S., Holden, D., Schrock, D., Thompson, S., and Wolkomir, M.: Generic Processes in the Reproduction of Inequality: An Interactionist Analysis, Soc. Forces, 79, 419-452, 2000.

Shakespeare, T.: Disabled People's Self-organisation: a new social movement?, Disability, Handicap \& Society, 8, 249-264, 1993.

Timár, J.: Lessons from Postsocialism: What's Left for Emerging Critical Geography to Do in Hungary?, Antipode, 35, 24-33, 2003.

Watson, N.: The Dialectics of Disability. A Social Model for the 21st Century?, in: Implementing the Social Model of Disability: Theory and research, edited by: Barnes, C. and Mercer, G., Leeds, The Disability Press, 101-117, 2004.

Woods, M.: Deconstructing rural protest: the emergence of a new social movement, J. Rural Stud., 19, 309-325, 2003. 